lus glabra); the last four are new food plants. Mytilaspis ulmi L. (Syn. M. pomorum Bouché) has now been recorded throughout the world from 46 different food plants. I have it from $\mathbf{2 2}$ in Mass. Chionaspis furfurus Fitch is found on 14 different food plants in Mass.

(22) Aulacaspis elegans Leon, on
Cycas revoluta; this together with Lecanium hemisphaericum Targ. and Dactylopim longispinus, were on the same plant in the Springfield natural history museum. Previously recorded Coccids found at Springfield are Gossyparia ulmi, Phenacoccus aceris, Ripersia kingii, Lecanium nigrofasciatum and Mytilaspis ulmi.

\title{
LIFE HISTORIES OF NORTH AMERICAN GEOMETRIDAE.-XV.
}

BY HARRISON G. DYAR, WASHINGTON, D. C.

Racheospila saltusaria Hulst.

$E g g$ (dissected from moth). Ellipticalstrongly flattened above and below, but rounded, one end depressed from side view; shagreened, scarcely reticulate; size $.6 \times .5$ $\times .3 \mathrm{~mm}$. Color, orange red.

Stage $I$. Head round, slightly bilobed, pale brownish; width $.25 \mathrm{~mm}$. Joint 2 high, collared in front, the collar notched centrally; otherwise cylindrical, smooth, slender, the segments bent angularly when walking; pale yellowish, shining; feet normal, short. Skin rather sparsely minutely granular. No tubercles or setae except on the anal feet and a pair on anal plate, pale, slightly enlarged at tips. Anal plate long, pointed behind, round before with two conical, thick, subanal prongs, approximate and longer than the plate.

Stage II. Head rounded, the lobes bluntly highly produced, a wide notch between; yellowish, sutures and mouth brown, ocelli black; width $.33 \mathrm{~mm}$. Body cylindrical, joint 2 with two high cones in front; anal plate long, rounded, the thick subanal prongs projecting beyond. Greenish yellow, smooth, no marks, minutely frosted. Later an interrupted dorsal brown line appears.
Stage III. Head lobes sharply conically produced; green, shaded with brown over the sides; width $.55 \mathrm{~mm}$. A high double point on joint 2 ; anal plate elliptical, pointed, the thick subanal prongs reddish. All else smooth, subgranular frosted, green, a brown dorsal line represented by dashes in the incisures.

Stage IV. Head flat before, the lobes produced into thick conical horns, slightly constricted centrally; clypeus rather high ; dark brown, face frosted with whitish, and with frosted streaks over the lobes especially behind; mouth black brown; width $\mathrm{I} \mathrm{mm}$. Body slender, uniform, a large single green hump on joint 2 with two approximate, dark brown horns on the summit, a little recurved outwardly. Anal plate long, pointed behind, excavate before; shields of anal feet large, triangular, excavate below posteriorly. Feet of joint Io small, approximate to the anal ones. Body stiff, angular when walking, dark green, very faintly frosted with white granules posteriorly; a series of dark vinousbrown intersegmental dashes, frosty edged, connected by a darker green stripe; on joints Io to 12 these are contracted to a continuous line. Anal plate green; thick prongs vinous, 
white dusted. Thoracic feet brown. No tubercles or setae. Spiracles minute, brown. Central segments long drawn out, the ends contracted.

Stage $V$. Head lobes produced into high cones as before but each with a blunt low protuberance before and a little inwardly; mossy granular, minutely mottled white, brown and black, finely, pulverulently ; width I.7 $\mathrm{mm}$. Thoracic feet colored like head, short, held close to it. Joint 2 horned with two bark gray points at the tip. A low double blackish lump below the spiracle of joint 6 corresponding to tubercles iv and $v$, varying in development in different specimens. Ends much contracted, the central part long drawn out, slender. Feet short; anal plate pointed cordate; anal leg shields trilobate. Leaf green, minutely white frosted with dense granules, part of them green; a series of small dorsal intersegmental black-vinous streaks with whitish frosted edges. Tubercles indicated by dark spots, themselves obsolete. Joints ro to $\mathbf{I}_{3}$ gray and brownish shaded; a dark patch before the foot of joint ro; venter pale. The larva is a remarkable mimic of the young twigs of its food plant, Condalia ferrea.

Cocoon an imperfect net of threads between leaves. Pupa light brown with darker cases and a broken dorsal line. Larvae from Palm Beach, Florida ; stage I found Feb. 26th, mature larva May $15^{\text {th, }}$, the growth very slow for a subtropical insect. Probably breeds continuously, though much time is spent in the larval stage. Stage IV in one example lasted four weeks.

\section{NEW ENGLAND ORTHOPTERA.}

Mr. Samuel Henshaw sends the following additions (species or localities) to the List of New England Orthoptera published in the September Psycire.

Labia burgessi Boston, Mass.

Ischnoptera pennsylvanica Rhode Island.

Nyctobora sericea Springfield, Mass.

Periplaneta australasiae Wellesley, Mass. Stagmomantis carolina Rhode Island.

Atlanticus pachymerus Brookline, Mass.

Oecanthus quadripunctatus Cambridge, Blue Hill, and Nantucket, Mass.

Oecanthus nigricornis Jaffrey, N. H., Cambridge and Blue Hill, Mass.

Oecanthus angustipennis Cambridge, Mass. Oecanthus pini Gloucester, Mass.

Gryllotalpa borealis Vt.

\section{MANTIS RELIGIOSA IN AMERICA.}

Prof. M. V. Slingerland has just sent me for determination a female specimen of this insect, reared at Ithaca from eggs received from Rochester, N. Y., where, according to him, "the insect has established itself." It is the first time it has been reported in the New World so far as I know. It occurs in southern Europe and in Asia as far as Hindustan and Java and in Africa as far south as Zanzibar.

S. H. Scudder.

Guide to the Genera and Classification of the Orthoptera of North America north of Mexico. By Samuel H. Scudder. 90 pp. $8^{\circ}$.

Contains keys for the determination of the higher groups as well as the nearly 200 genera of our Orthoptera, with full bibliographical aids to further study. Sent by mail on receipt of price $\$ \mathbf{r} .00$.

E. W. Wheeler, zo Boylston Street, Cambridge, Mass. 

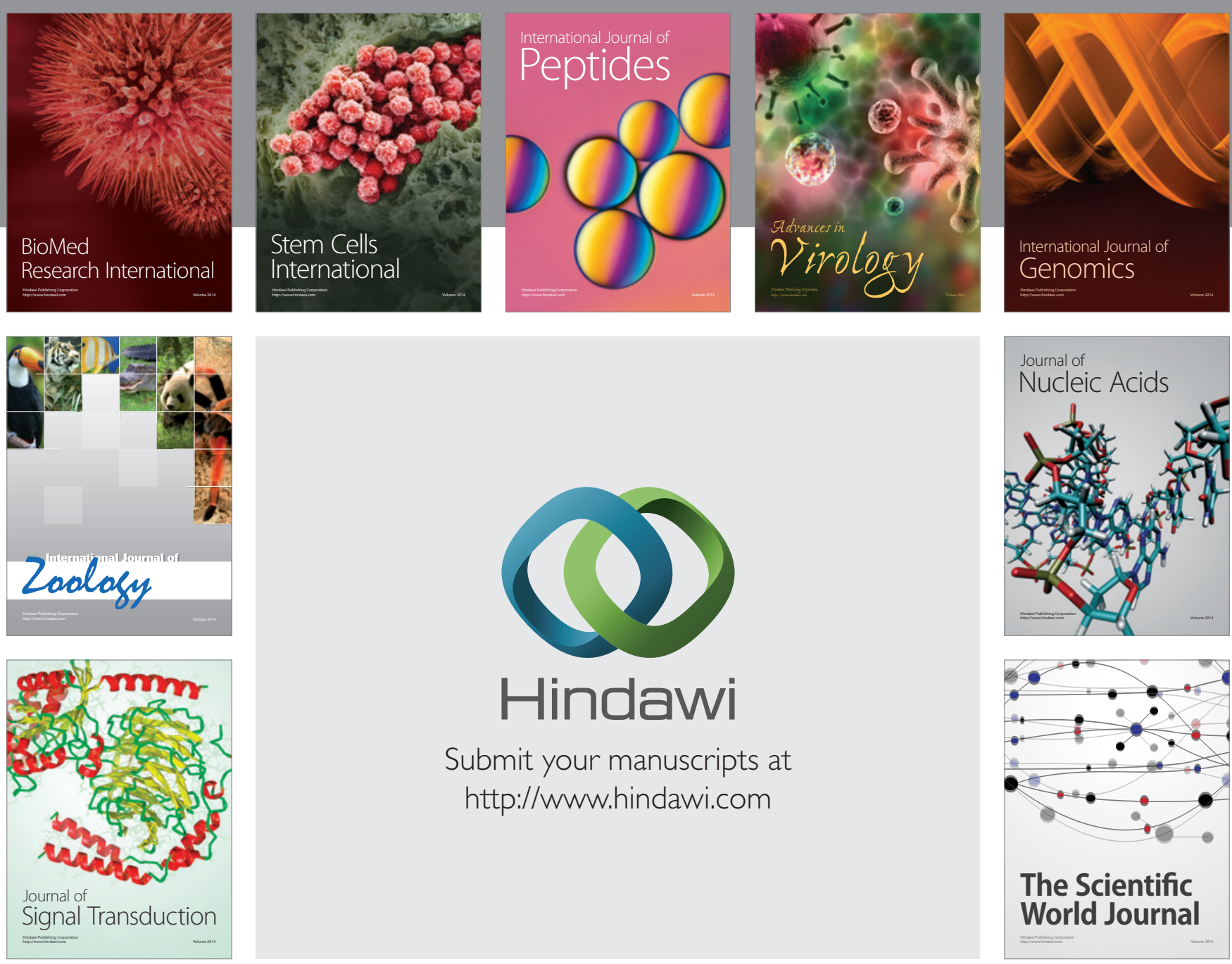

Submit your manuscripts at

http://www.hindawi.com
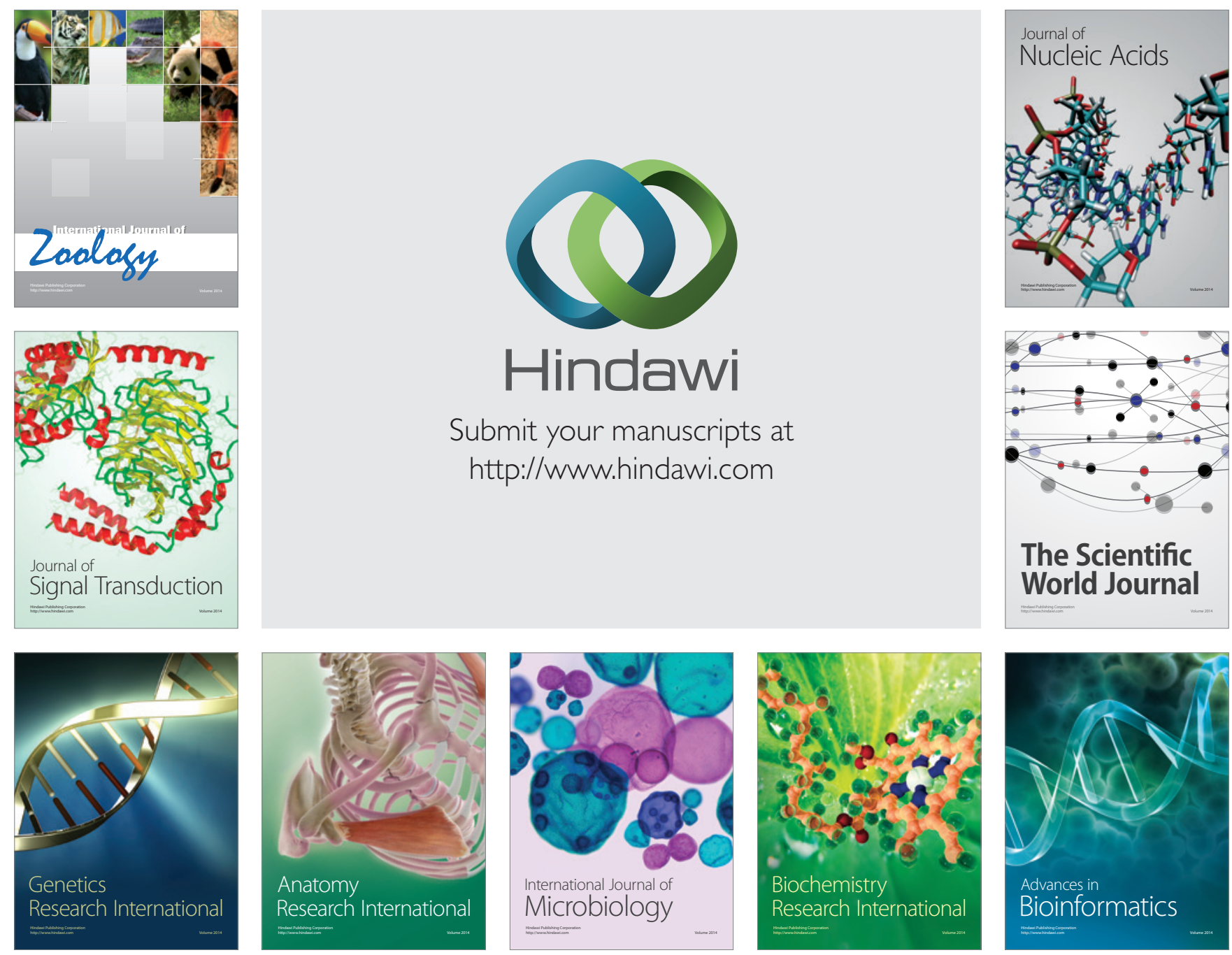

The Scientific World Journal
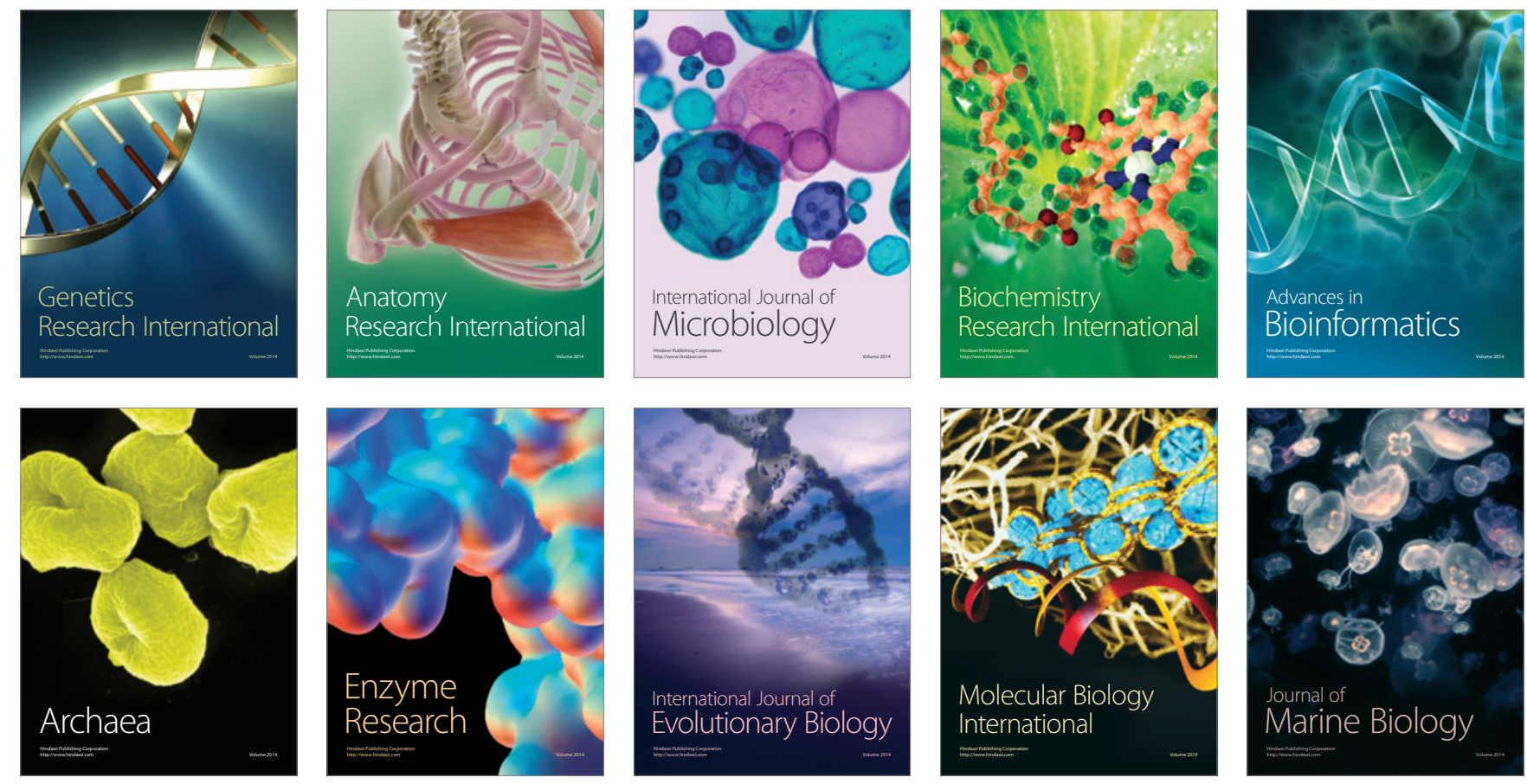